\title{
Woody Species Composition, Structure and Regeneration Status in Higelely Dry Forest, Eastern Ethiopia: Implication for Conservation Priority
}

\author{
Befkadu Mewded*, Sisay Alemu, Debeli Chala, Hailu Wondu \\ Forest and Range Land Plant Diversity Directorate, Ethiopian Biodiversity Institute, Addis Ababa, Ethiopia
}

Email address:

mewded2013@gmail.com (B. Mewded)

${ }^{*}$ Corresponding author

To cite this article:

Befkadu Mewded, Sisay Alemu, Debeli Chala, Hailu Wondu. Woody Species Composition, Structure and Regeneration Status in Higelely Dry Forest, Eastern Ethiopia: Implication for Conservation Priority. Plant. Vol. 9, No. 3, 2021, pp. 36-47. doi: 10.11648/j.plant.20210903.11

Received: May 17, 2021; Accepted: July 6, 2021; Published: July 15, 2021

\begin{abstract}
Dry forests are potentially contributed for the local community livelihood, microclimate stability and biodiversity conservation. However, appropriate emphasis has not given for its sustainability management. Our study aims to study the woody species diversity, vegetation structure, and recruitment and regeneration status in Higelely dry forest of Somali National Regional State of Ethiopia for the purpose of conservation priority. Systematic sampling following the transect lines and sample plots employed to collect all necessary data. Data were analyzed using access software which was designed for the purpose of forest genetic resource conservation database and data analysis tool. Forty two woody species belongs to 21 genera and 15 families were recorded. The richest families were Fabaceae and Burseraceae (represented by 11 and 7 species each). 1112.97 individuals of woody species per ha was recorded in Higelely forest. Acacia oerfota and Acacia mellifera were the top specie with higher stem numbers per ha. More than $67 \%$ of the individuals in the forest had DBH/DSH $\leq 7.5 \mathrm{~cm}$ and $90 \%$ of the individuals had a height $\leq 5 \mathrm{~m}$. The most ecologically important species in Higelely forest were Acacia oerfota, Acacia mellifera, and Acacia bussie. Whereas, Ipomoea donaldsonii, Commiphora africana, and Acacia drepanolobium were the most threatened species in all criteria's of IVI, population structure and regeneration status and are the first prioritized for conservation measures. The total density of 1047.3 seedling and 3033.77 sapling individuals per ha was recorded in Higelely forest. In general, the vegetation structure, population recruitment and regeneration status of some species indicates, Higelely forest is under poor conservation status. Therefore, for the conservation of woody species in Higelely dry forest, appropriate conservation measures such as in-situ (to allow natural regeneration) and cold room seed storage methods are recommended.
\end{abstract}

Keywords: Conservation Priority, Dry Forest, Higelely, Population Structure, Regeneration Status

\section{Introduction}

The major causes of forest destruction in Ethiopia are: increasingly intensive use of land for agriculture and livestock, tree cutting for fuel wood and construction materials, forest fires and human settlement [1-6]. These major causes of forest destruction are very much interrelated to each other and are also in one way or another related to the population growth of the country [7, 2]. According to Ayele [8], the population growth rate of Ethiopia is estimated to be $2.5 \%$ year $^{-1}$. The population growth is not backed with economic growth of the country and this has a great impact on the natural resources, especially on the forest land.
The extent of forest destruction is also increasing from time to time due to an escalating demand of land for cropping, grazing and fuel wood. Fuel wood is the major energy source of the country. The weighted average of annual per capita energy consumption for the households of the country is 1.2 $\mathrm{m}^{3}$ or $241 \mathrm{~kg}$ of oil equivalent [9] and from this, according to Beyene [10], 96\% of the nation's energy comes from biomass source and $85 \%$ of it is derived from fuel wood.

The rapid deforestation rate is also accompanied by a variety of environmental problems. The depletion and degradation of the forest resources affects the whole ecosystem [11-14]. Deforestation has resulted in soil erosion, loss of soil fertility, loss of reliable water supply, loss of 
habitat for wildlife and climate change.

By considering this problem, the Ethiopian biodiversity institute works to conserve the forest genetic resources through different conservation strategy. The overall objective of forest resource conservation is to contribute towards attaining a sustainable development of the economic, socio-cultural and ecological values of the forest ecosystems. The purpose is to protect and conserve the forest genetic resources of Ethiopia according to appropriate concepts and strategies. To attain its purpose, Ethiopian biodiversity institute has embarked on inventories of woody plant diversity surveys in selected forest areas throughout the country. Higelely forest is one of the selected forests for this inventory work. This forest is located in the eastern part of the country and its vegetation belongs to Acacia-Commiphora woodland and wooded grassland vegetation type.

The forest resources found in the eastern parts of the country are least conserved while contain higher species richness and diversity of dry land habitats. Higelely forest is one of those forests facing high risks due to different human activities such as logging for charcoal and other purpose and overgrazing and browsing by camels and other domestic animals. Likewise in most forest areas of Ethiopia, there is a common feature of destructive and unsustainable forest resource utilization. This unsustainable and destructive exploitation of the forest has caused tremendous forest degradation leading to rareness and final extinction of the forest species. Therefore, there is an urgent need to study the woody plant species diversity and determine their current conservation status in order to establish appropriate genetic conservation methods. This activity is one of the recommendable move to conserve and sustainable utilize the disappearing natural resources in the area. The study was conducted to achieve the specific objectives of determine the woody species composition; structure; regeneration status; and compilation of a priority list of indigenous woody plant species for conservation concern.

\section{Methodology}

\subsection{Study Area Description}

Higelely forest is administratively located in Deghabur district, Jerer Zone in Somali National Regional State of Ethiopia. Geographically the forest is located between $8^{\circ} 25^{\prime} 35.24^{\prime \prime}$ and $8^{\circ} 26^{\prime} 46.18^{\prime \prime} \mathrm{N}$ and 43 $3^{\circ} 33^{\prime} 13.67^{\prime \prime}$ and $43^{\circ} 34 ' 34.7^{\prime \prime}$ E, $15 \mathrm{~km}$ from Deghabur district to Jigjiga town (east direction). The altitudinal range of this forest is between $1266-1340 \mathrm{~m}$ a. s. 1. The topography of the area is plane level except the upper north part of the forest. Higelely forest has narrow-leaved deciduous physiognomy.

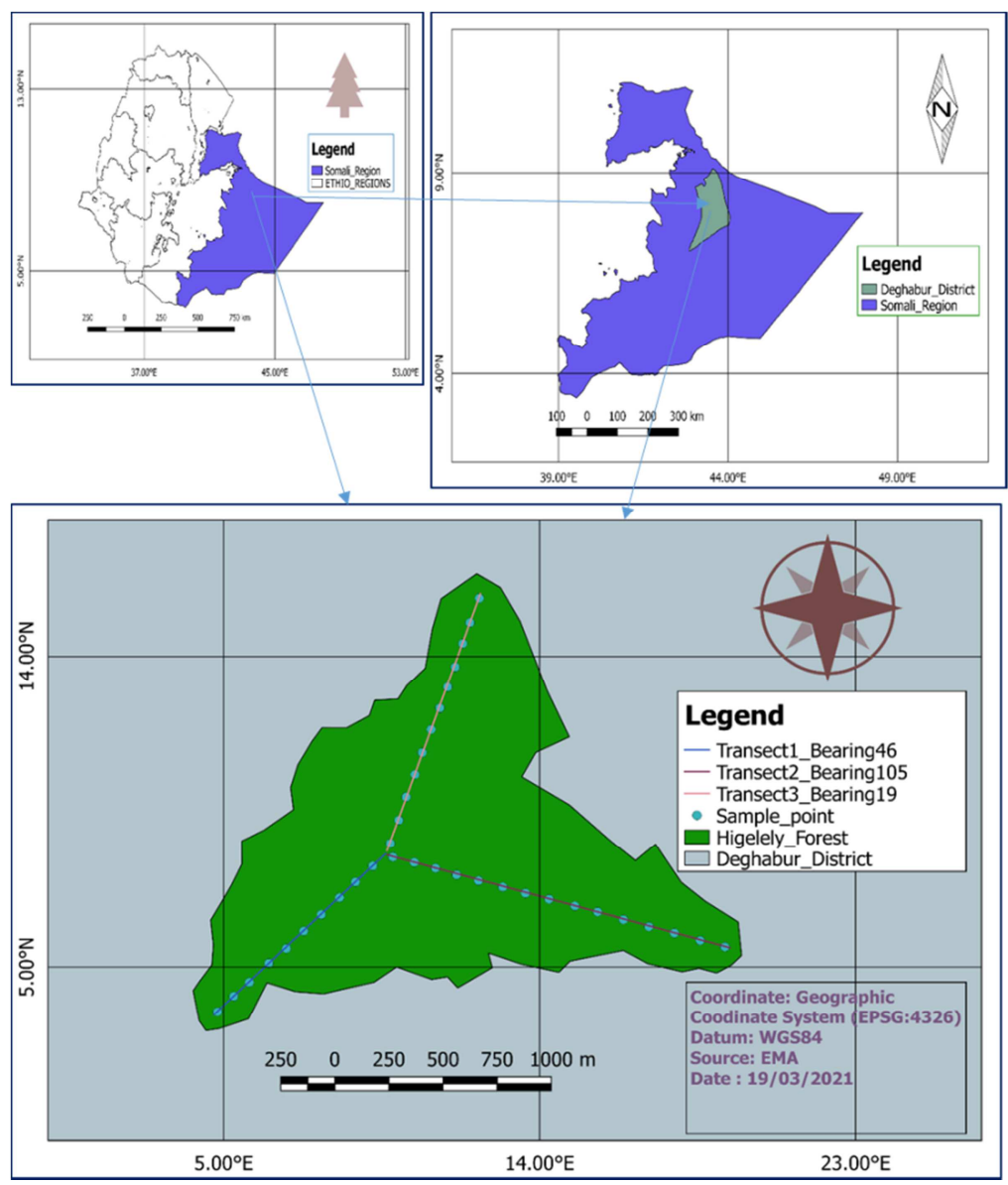

Figure 1. Map of Higelely dry forest. 


\subsection{Sampling Design}

The woody plant inventory of Higelely dry forest was carried out in wet season (from October 09, 2020 - October 24, 2020) to take unbiased regeneration sampling of woody species.

Systematic sampling was employed for the purpose of woody plant inventory. This sampling technique involves setting location of sampling plots at regular or systematic intervals along a predetermined transect line [15]. The optimum number of the transect lines, their spatial distribution and the total coverage was determined following a preliminary reconnaissance of the forest.

A total of three transects and 37 sample plots were laid. The beginning and end points (the latitude and longitude) of the selected transect was marked using GPS. The sample plots were distributed with specified location fixed at a regular interval of $100 \mathrm{~m}$ distance. The stand structure was enumerated in the $20 \times 20 \mathrm{~m}$ size sample plots.

\subsection{Data Collection}

\subsubsection{Vegetation Data}

Each woody plant within sample plots was measured and plant specimens were collected for every woody species. Woody species data were collected with local names.

The diameter and height of all tree and shrub species $>2.5$ $\mathrm{cm}$ in diameter were measured and the growth habit was described. The DSH (diameter at stump height) (at a height of $0.3 \mathrm{~m}$ from the ground) and DBH (Diameter at breast height) ( $1.3 \mathrm{~m}$ from the ground) was measured over bark using a Caliper. The DSH measurement was taken for shrub species and DBH measurement for tree species. The heights of all tree/shrub species were measured by Suunto clinometer.

All seedlings and saplings of woody species were also enumerated from two, $2 \times 5 \mathrm{~m}$ sub plots inside each main plot. The sub plots were laid at the beginning and endpoints of the main plots and for each sample plot $20 \mathrm{~m}^{2}$ of sub plots were laid.

\subsubsection{Physiographic Data Collection}

Geographic location, relief, slope gradient, and disturbance condition of each sample plots were determined as follows. Geographic location such as altitude, longitude and latitude of each sample plots was determined using Garmin GPS 72. The slope gradient was also measured using the Clinometer oriented with the main slope gradient of the field.

The extent of external pressure on the forest was assessed following an arbitrary scale of disturbance with a particular focus on the following activities. Agricultural encroachment, logging (in this case logging is taken to mean extraction of wood from the forest by way of felling trees), charcoal production, fire, debarking, pollarding, lopping, pruning, grazing and browsing. For each disturbance type a scale of disturbance from $0-5$ was considered. Zero for where not disturbance recorded, and five for highly disturbed plot.

\subsection{Data Analysis}

The vegetation data analysis was performed by Access software which was designed for forest genetic resource conservation database and data analysis tool [16]. The structural analysis of the woody plants, Basal Area and Dominance calculations were also done by using this software. Accordingly the following parameters were calculated:

a) Density of all tree/shrub species $=\frac{\text { Total number of stems of all tree } / \text { shrub species }}{\text { Sample size in } h a}$

b) Density of each individual tree/shrub $=$

Total number of stems encountered for a given tree/shrub

c) Relative density of each individual tree/shrub= Number of stems of each individual tree/shrub $\times 100$ Total number of stems of all tree/shrub

The frequency, Relative frequency, Basal area (Ba), Dominance and Relative dominance were also calculated as follows for each tree $/$ shrub species with $\mathrm{DBH} / \mathrm{DSH}>2.5 \mathrm{~cm}$ :

a) Frequency= $\frac{\text { Number of quadrates in which a species recorded }}{\text { Total number of quadrates }} \times 100$

b) Relative frequency $=\frac{\text { Frequency of a species }}{\text { Sum frequency of all tree } / \text { shrub species }} \times 100$

c) $\mathrm{Ba}=\pi \mathrm{d}^{2} / 4$, where $\mathrm{Ba}=$ basal area, $\pi=22 / 7$ or 3.14 , $\mathrm{d}=$ diameter at breast height or stump height

d) Dominance=Mean Ba per tree/shrub species x Density of a tree/shrub species

e) Relative Dominance $=\frac{\text { Mean } B \text { of a tree } / \text { shrub species }}{\text { Mean BA of all tree } / \text { shrub species }} \times$ 100

f) Importance Value Index=Relative density +Relative frequency + Relative Dominance

Diameter and height class distribution analysis were also done by using Access software.

\section{Results and Discussion}

\subsection{Forest Disturbance}

Higelely forest is one of the heavily exploited forests in the past and still at present. Five disturbance types were encountered in the studied forest such as browsing, grazing, logging, flood and fire. From the assessed 37 sample plots, $35 \%$ were heavily disturbed by grazing; $32 \%$ moderately and $43 \%$ very seriously disturbed by browsing; $40.5 \%$ heavily and $37.8 \%$ very seriously disturbed by logging. In over all $100 \%$ of the assessed sample plots were disturbed by browsing, $97 \%$ by logging and $43 \%$ by grazing (Table 1 ).

\subsection{Floristic Composition}

A total of 42 woody species were collected from Higelely dry forest (Table 2). Out of the 42 species encountered in the forest, 39 have been identified to the species level, two has been identified to genus level and one has been identified to family level. The specimen identified so far belongs to 21 genera and 15 families. The diverse families were Fabaceae and Burseraceae (represented by 11 and 7 species each). The 
diverse genera of the forest were Acacia and Commiphora (represented by 10 and 6 species, respectively). The growth habit distribution of all the species recorded in Higelely forest showed that $52.4 \%$ were trees and $47.6 \%$ were shrub species. Similar number of woody species recorded in similar dry forest in Metema area [16]. Similarly, approximated numbers of woody species were recorded from Borena dry land vegetation [17].

Table 1. Disturbance types and scales of disturbance observed across sample plots in Higelely dry forest.

\begin{tabular}{|c|c|c|c|c|c|c|}
\hline \multirow{2}{*}{ Types of disturbance } & \multicolumn{5}{|c|}{ Scale of disturbance } & \multirow{2}{*}{ Percent of total } \\
\hline & Non/ Negligible & Very light & Light & Moderate & Intensive & \\
\hline Grazing & - & - & $3^{*}$ & $13^{*}$ & - & 43 \\
\hline Flood & - & $2^{*}$ & $2^{*}$ & $2^{*}$ & $4^{*}$ & 32.4 \\
\hline Fire & - & $1^{*}$ & $2^{*}$ & - & $1^{*}$ & 10.8 \\
\hline Browsing & - & $5^{*}$ & $12^{*}$ & $4^{*}$ & $16^{*}$ & 100 \\
\hline Logging & - & $2^{*}$ & $5^{*}$ & $15^{*}$ & $14^{*}$ & 97 \\
\hline
\end{tabular}

*Number of sample plots encountered in each disturbance scale.

Table 2. List of woody species recorded from Higelely forest.

\begin{tabular}{|c|c|c|c|}
\hline Scientific Name & Family & Habit & To Ethiopia \\
\hline Acacia brevispica Harms. & Fabaceae & Shrub & Indigenous \\
\hline Acacia bussei Harms ex Sjostedt. & Fabaceae & Tree & Indigenous \\
\hline Acacia drepanolobium Harms ex Sjostedt. & Fabaceae & Shrub & Indigenous \\
\hline Acacia mellifera (Vahl) Benth. & Fabaceae & Tree & Indigenous \\
\hline Acacia nilotica (L.) Willd. ex. Del. & Fabaceae & Tree & Indigenous \\
\hline Acacia oerfota (Forssk.) Schweinf. & Fabaceae & Shrub & Indigenous \\
\hline Acacia sp & Fabaceae & Tree & \\
\hline Acacia tortilis (Frossk.) Hayne & Fabaceae & Tree & Indigenous \\
\hline Albizia amara (Roxb.) Boiv. & Fabaceae & Tree & Indigenous \\
\hline Balanites glabra Mildbr. \& Schlecht. & Balanitaceae & Tree & Indigenous \\
\hline Berchemia discolor (Klotzsch) Hemsl. & Rhamnaceae & Tree & Indigenous \\
\hline Boscia minimifolia Chiov & Capparidaceae & Shrub & Indigenous \\
\hline Boswellia microphylla Chiov. & Burseraceae & Shrub & Indigenous \\
\hline Combretum molle R. Br. ex G. Don. & Combretaceae & Tree & Indigenous \\
\hline Commiphora boranensis Vollesen & Burseraceae & Tree & Indigenous \\
\hline Commiphora corrugata Gillett \& Vollesen & Burseraceae & Shrub & Indigenous \\
\hline Commiphora incisa Chiov. & Burseraceae & Tree & Indigenous \\
\hline Commiphora schimperi (Berg) Engl. & Burseraceae & Tree & Indigenous \\
\hline Commiphora truncata Engl. & Burseraceae & Tree & Indigenous \\
\hline Cordia monoica Roxb. & Boraginaceae & Tree & Indigenous \\
\hline Dobera glabra (Forssk.) Poir. & Salvadoraceae & Tree & Indigenous \\
\hline Dodonaea angustifolia L. f. & Sapindaceae & Shrub & Indigenous \\
\hline Grewia arborea (Forssk.) Lam. & Tiliaceae & Shrub & Indigenous \\
\hline Grewia bicolor Juss. & Tiliaceae & Tree & Indigenous \\
\hline Grewia flavescens Juss. & Tiliaceae & Shrub & Indigenous \\
\hline Grewia sp & Tiliaceae & Shrub & Indigenous \\
\hline Grewia tenax (Forssk.) Fiori & Tiliaceae & Shrub & Indigenous \\
\hline Ipomoea donaldsonii Rendle & Convolvulaceae & Shrub & Indigenous \\
\hline Ipomoea spathulata Hall. f. & Convolvulaceae & Shrub & Indigenous \\
\hline Salvadora persica L. & Salvadoraceae & Shrub & Indigenous \\
\hline Sida rhombifolia L. & Malvaceae & Shrub & Indigenous \\
\hline Solanum incanum L. & Solanaceae & Shrub & Indigenous \\
\hline Solanum jubae Bitter & Solanaceae & Shrub & Indigenous \\
\hline Sterculia setigera Del. & Sterculiaceae & Tree & Indigenous \\
\hline Terminalia brownii Fresen. & Combretaceae & Tree & Indigenous \\
\hline Ziziphus spina-christi L. & Rhamnaceae & Tree & Indigenous \\
\hline Dulfalid & Capparidaceae & Shrub & - \\
\hline
\end{tabular}

\subsection{Vegetation Structure}

\subsubsection{Species Dimension}

The ecological dominance and economic significance of trees is to a great extent a function of their size. The superior size of trees is a result of their continued increase in height and diameter. The maximum DBH attained in Higelely forest was by Dobera glabra followed by Terminalia brownii and 
Ziziphus spina-christi with maximum DBH of 65, 54, and 38 $\mathrm{cm}$, respectively. Higher mean DBH was also attained by Terminalia brownii followed by Ziziphus spina-christi and Dobera glabra with mean DBH of 34.6, 33.6 and $28 \mathrm{~cm}$, respectively. The maximum height in this forest $(18 \mathrm{~m})$ was attained by Terminalia brownii followed by Ziziphus spinachristi and Acacia bussie (15 m each). Higher mean height was attained by Ziziphus spina-christi followed by Terminalia brownii and Dobera glabra with average height of 14.7, 11.8 and $7.5 \mathrm{~m}$ (Table 3).

Table 3. The DBH/DSH and height distribution of species.

\begin{tabular}{|c|c|c|c|c|}
\hline \multirow[t]{2}{*}{ Species } & \multicolumn{2}{|c|}{ DSH/DBH } & \multicolumn{2}{|c|}{ Height } \\
\hline & Max & Mean & Max & Mean \\
\hline Acacia brevispica & 8.8 & 5.1 & 4 & 3.29 \\
\hline Acacia bussie & 35 & 11.51 & 15 & 4.92 \\
\hline Acacia drepanolobium & 10.6 & 10.6 & 3.5 & 3.5 \\
\hline Acacia etbaica & 26 & 15.75 & 8 & 5.5 \\
\hline Acacia mellifera & 35 & 7.33 & 12 & 3.84 \\
\hline Acacia nilotica & 22 & 12.65 & 6 & 4.13 \\
\hline Acacia oerfota & 24 & 5.7 & 9 & 3.46 \\
\hline Acacia senegal & 18 & 4.47 & 6 & 3 \\
\hline Acacia sp & 9 & 9 & 4.5 & 4.5 \\
\hline Acacia tortolis & 31.5 & 10.78 & 8 & 4.59 \\
\hline Albizia amara & 9.3 & 8.7 & 3.5 & 3.5 \\
\hline Balanites glabra & 24 & 9.87 & 10 & 4.08 \\
\hline Berchemia discolor & 36 & 18.58 & 11.5 & 7.04 \\
\hline Boscia minimifolia & 28 & 7.46 & 10 & 3.25 \\
\hline Boswellia microphylla & 12 & 7.75 & 5 & 3.09 \\
\hline Combretum molle & 25 & 10.54 & 12 & 2.67 \\
\hline Commiphora africana & 12.6 & 8.9 & 4 & 3.5 \\
\hline Commiphora boranensis & 18 & 14.17 & 5 & 4.33 \\
\hline Commiphora corrugata & 14 & 8.7 & 5 & 3.27 \\
\hline Commiphora incisa & 24 & 10 & 4 & 2.75 \\
\hline Commiphora schimperi & 28 & 9.42 & 8 & 3.25 \\
\hline Commiphora truncata & 8.2 & 6 & 3 & 2.75 \\
\hline Cordia monica & 4.2 & 2.61 & 3 & 2.6 \\
\hline Dobera glabra & 65 & 28.15 & 10 & 7.5 \\
\hline Dodonaea angustifolia & 3.2 & 3.2 & 2.5 & 2.5 \\
\hline Dulfelid & 2.5 & 2.5 & 3.1 & 1.77 \\
\hline Grewia arborea & 4.2 & 3.75 & 3 & 2.9 \\
\hline Grewia bicolor & 5.5 & 5.5 & 3.5 & 3.5 \\
\hline Grewia sp & 2.5 & 2.5 & 2 & 2 \\
\hline Grewia tenax & 2.5 & 2.5 & 2 & 1.6 \\
\hline Ipomoea donaldsonii & 3.1 & 3.1 & 1.5 & 1.5 \\
\hline Maerua triphylla & 3.5 & 3.25 & 3 & 2.63 \\
\hline Opilia campestris & 6.2 & 6.2 & 4 & 3.63 \\
\hline Salvadora persica & 14 & 11.4 & 7 & 5.5 \\
\hline Solanum juboe & 3.5 & 3.36 & 3 & 2.79 \\
\hline Sterculia setigera & 35 & 22.2 & 8 & 5.3 \\
\hline Terminalia brownii & 54 & 34.61 & 18 & 11.76 \\
\hline Ziziphus spina-christi & 38 & 33.67 & 15 & 14.67 \\
\hline
\end{tabular}

\subsubsection{Vertical Structure}

According to Work [17], classification the upper story is taken as tree height $>2 / 3$ of top height, middle story as tree height between $1 / 3-2 / 3$ of the top height and the lower story as tree height $<1 / 3$ of the top height. The top height attained in Higelely dry forest was $18 \mathrm{~m}$; therefore, the upper story of this forest was $13-18 \mathrm{~m}$, middle story $7-12 \mathrm{~m}$ and lower story $<7 \mathrm{~m}$. The upper canopy of this forest was dominated by Terminalia brownii, Ziziphus spina-christi, Acacia bussei, Acacia mellifera and Combretum molle. The middle canopy is mainly dominated by Boscia minimifolia and Acacia oerfota. Smaller tree and shrub species of this forest were species in genus Grewia, Ipomoea and Solanum.

The lower story has a higher density and species composition as compared to the middle and upper story's.
The upper story has the lowest density and species composition. This shows the predominance of shrubby species and small sized individuals. Even though some species are limited to the middle and lower strata and unable to reach the upper story [18], it indicates the forest had been in serious exploitation of higher size woody species. Some of the species such as Acacia bussei and Acacia mellifera encountered in the upper story are also encountered in the middle and lower story. Such kinds of species are considered to be "species with a regular vertical distribution" [17].

\subsubsection{Frequency}

All the species were grouped into five frequency classes. These frequency classes are: species with frequency value of $81-100=\mathrm{A}, 61-80=\mathrm{B}, 41-60=\mathrm{C}, 21-40=\mathrm{D}$ and $0-$ $20=\mathrm{E}$. In this regard, five species was found in frequency 
class A and B. The most frequent species in this forest was: Acacia mellifera, Acacia bussei, Boscia minimifolia, Acacia oerfota and Balanites glabra (with a frequency value of $97.3 \%, 89.2,86.5,73$ and $64.9 \%$, respectively). Commiphora africana, Dodonaea angustifolia, Grewia bicolor, Ipomoea donaldsonii, Acacia drepanolobium, Combretum molle, Sterculia setigera and Ziziphus spinachristi were the least frequent species of this forest with frequency value of $2.7 \%$. Eighty four percent of the species were found in frequency class $\mathrm{D} / \mathrm{E}$ (Figure 2). The relative frequency also showed $10.8 \%$ of the species had a relative frequency of $>10 \%, 29.7 \%$ had $1-10 \%$ and $59.5 \%$ had a relative frequency of $<1 \%$.

The frequency gives an approximate indication of the homogeneity or heterogeneity of a vegetation stand [19]. According to Fangliang [20], high values in frequency class $\mathrm{A} / \mathrm{B}$ and low values in $\mathrm{D} / \mathrm{E}$ indicate constant or similar species composition. High values in lower frequency classes and low values in higher frequency classes on the other hand indicate a high degree of floristic heterogeneity [21]. Therefore, it could be concluded that Higelely forest has heterogeneous species composition except five most frequent species listed above.

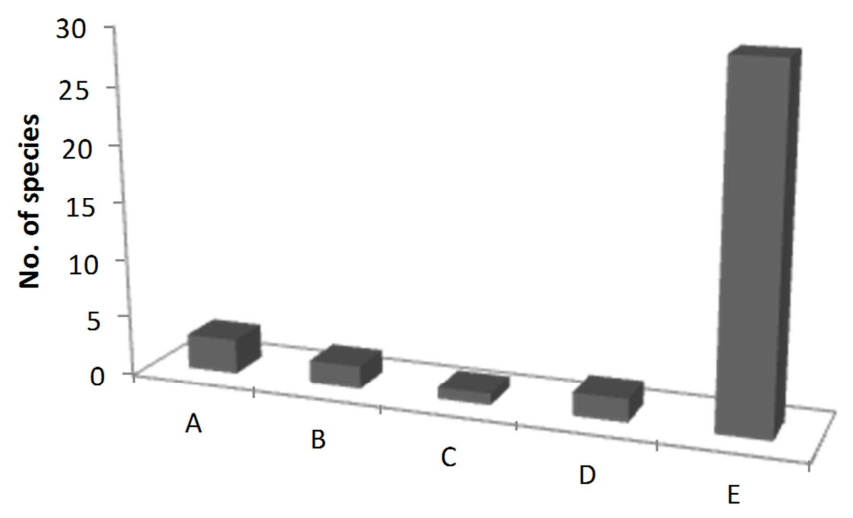

Frequency class

Figure 2. Frequency class distribution of all species recorded in Higelely dry forest (Class $A=81-100, B=61-80, C=41-60, D=21-40$ and $E=0-$ 20).

\subsubsection{Density}

The total density of the species in Higelely dry forest was 1112.97 individuals (stems) per ha. The density of all species with DBH/DSH over $10 \mathrm{~cm}$ in Higelely forest was found to be 140.5 individuals per ha. This number is lower and might be below normal coverage with comparing to the total density of the species recorded.

The species recorded in this forest had unequal density and it could be said that the forest is dominated by few species (Figure 3). About $83 \%$ of the total number of stems of the forest was accounted for six species. These include: Acacia oerfota, Acacia mellifera, Acacia senegal, Acacia bussie, Boscia minimifolia and Balanites glabra. The species with least density in this forest was Acacia sp.

The density class distributions of species showed that only Acacia oerfota and Acacia mellifera were found in density class A with stems per ha of $>100$, (377 and 273 individuals per hectare, respectively). On the other extreme $68 \%$ of the species were found in density class D\&E with less than or equal to 10 numbers of individuals per hectare (Figure 4).

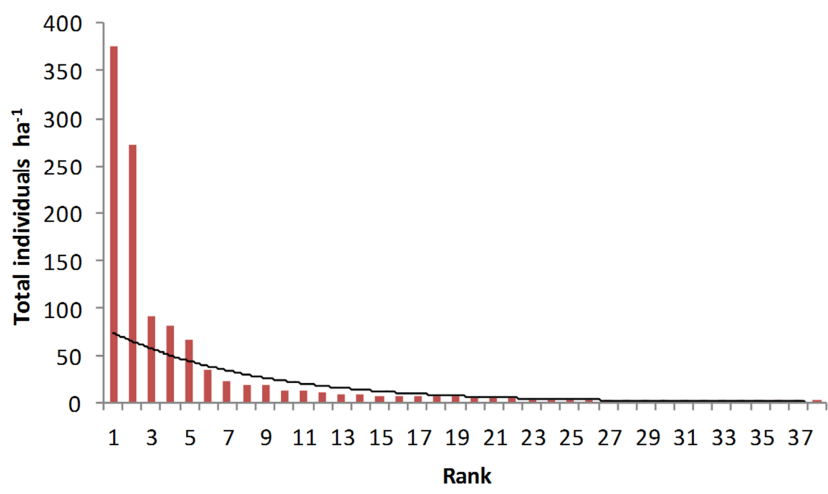

Figure 3. Number of individuals against their rank (abundance curve) of the species recorded in all quadrates.

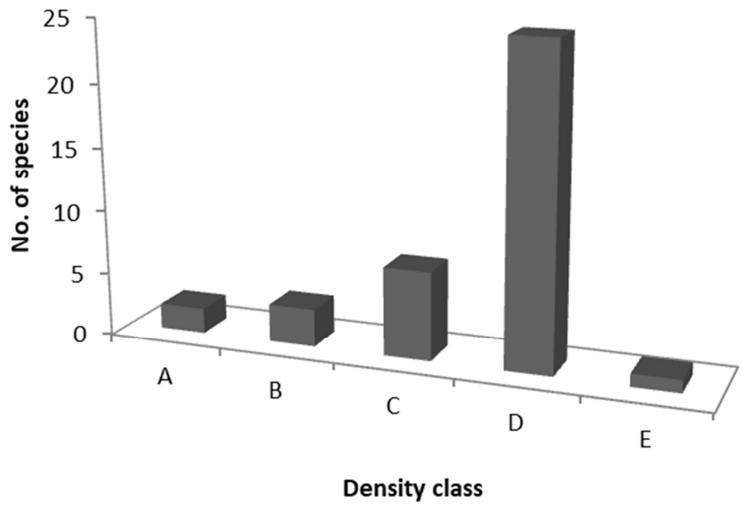

Figure 4. Density class distributions of all species (Class $A=>100, B=50.1$ $-100, C=10.1-50, D=1.1-10$ and $D=<1$ ).

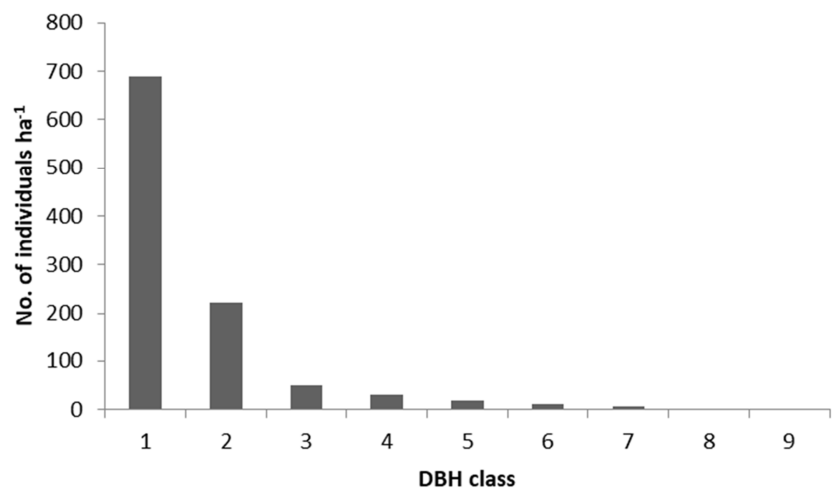

Figure 5. Density distribution in DBH classes (cm); Class $1=2.6-7.5,2=7.6$ $12.5,3=12.6-17.5,4=17.6-22.5,5=22.6-27.5,6=27.6-32.5,7=32.6-37.5$, $8=37.6-42.5$ and $9=>42.5$.

\subsubsection{Diameter and Height Class Distribution}

The diameter class distribution pattern of all the tree/shrub species showed an inverted J shape (Figure 5). More than 67\% of the individuals in the forest had $\mathrm{DBH} / \mathrm{DSH}$ in the range between $2.6-7.5 \mathrm{~cm}$ indicating the potential of the forest for recruitment and regeneration capability of if appropriate management practice is applied. On the other hand only $0.3 \%$ of these species attained diameter of $>37.5 \mathrm{~cm} \mathrm{DBH} / \mathrm{DSH}(3.2$ 
individuals per ha) and the low stocking level of mature trees confirmed that the forest was affected by serious exploitation. The species which attained diameter of $>37.5$ were: Terminalia brownii, Dobera glabra, and Ziziphus spina-christi.

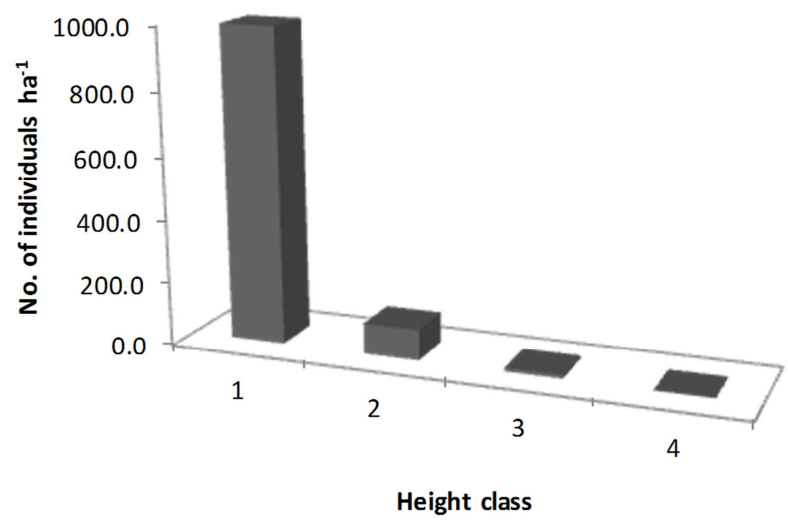

Figure 6. Density distribution in height classes $(\mathrm{m})$; Class $1=<5 \mathrm{~m}, 2=5.1-$ $10,3=10.1-15,4=15.1-20$.

The height class distribution pattern of all species also displays an inverted $J$ shape (Figure 6). The number of individual decreased as the height increased. About $90 \%$ of the species have a height less than or equal to $5 \mathrm{~m}$ and only Dobera glabra attained the maximum height class of Higelely dry forest (i.e., $>15 \mathrm{~m}$ ).

\subsubsection{Basal Area and Dominance}

The total basal area $\left(\mathrm{m}^{2} / \mathrm{ha}\right)$ of all species with $\mathrm{DBH} / \mathrm{DSH}>2.5 \mathrm{~cm}$ of Higelely forest was 0.57 . The basal area per ha coverage of Higelely forest is less than normal range. The highest proportion of mean Basal area in this forest was accounted to Terminalia brownii followed by, Ziziphus spina-christi and Dobera glabra (with mean Basal area value of $0.1,0.09$, and $0.07 \mathrm{~m}^{2} /$ ha respectively). Solanum juboe, Dodonaea angustifolia, Ipomoea donaldsonii, Maerua triphylla, Cordia monica, Dulfelid, Grewia sp, Grewia tenax were also found with little mean basal area $\left(<0.0011 \mathrm{~m}^{2} / \mathrm{ha}\right)$.

Species dominance is meant the basal area per ha coverage of each individual species in the forest. About $52.7 \%$ of the dominance was accounted by three species of the forest. These include: Acacia mellifera, Acacia oerfota, and Acacia bussei. The species with least dominance value in this forest were: Maerua triphylla, Ipomoea donaldsonii, Grewia sp and Dulfelid with dominance value of $<0.002$ (Table 4).

Table 4. The basal area and dominance of species in Higelely forest.

\begin{tabular}{|c|c|c|c|c|c|}
\hline Species & Total Stem No & Mean DSH/DBH & Mean BA & Density ha $^{-1}$ & Dominance \\
\hline Acacia mellifera & 505 & 11.51 & 0.01 & 272.97 & 1.58 \\
\hline Acacia oerfota & 697 & 7.33 & 0.00 & 376.76 & 1.22 \\
\hline Acacia bussie & 153 & 5.70 & 0.01 & 82.70 & 1.21 \\
\hline Terminalia brownii & 11 & 34.61 & 0.10 & 5.95 & 0.61 \\
\hline Dobera glabra & 12 & 28.15 & 0.08 & 6.49 & 0.50 \\
\hline Boscia minimifolia & 124 & 7.46 & 0.01 & 67.03 & 0.42 \\
\hline Balanites glabra & 65 & 9.87 & 0.01 & 35.14 & 0.32 \\
\hline Acacia tortolis & 33 & 15.75 & 0.01 & 17.84 & 0.20 \\
\hline Acacia senegal & 169 & 10.78 & 0.00 & 91.35 & 0.19 \\
\hline Acacia nilotica & 19 & 12.65 & 0.02 & 10.27 & 0.18 \\
\hline Commiphora schimperi & 34 & 9.42 & 0.01 & 18.38 & 0.16 \\
\hline Ziziphus spina-christi & 3 & 33.67 & 0.09 & 1.62 & 0.15 \\
\hline Combretum molle & 24 & 10.54 & 0.01 & 12.97 & 0.14 \\
\hline Sterculia setigera & 5 & 22.20 & 0.05 & 2.70 & 0.12 \\
\hline Commiphora corrugata & 11 & 14.17 & 0.01 & 5.95 & 0.04 \\
\hline Commiphora incisa & 6 & 8.70 & 0.01 & 3.24 & 0.04 \\
\hline Boswellia microphylla & 11 & 7.75 & 0.01 & 5.95 & 0.03 \\
\hline Commiphora boranensis & 3 & 8.90 & 0.02 & 1.62 & 0.03 \\
\hline Salvadora persica & 3 & 11.40 & 0.01 & 1.62 & 0.02 \\
\hline Grewia bicolor & 10 & 5.50 & 0.00 & 5.41 & 0.01 \\
\hline Dodonaea angustifolia & 23 & 3.20 & 0.00 & 12.43 & 0.01 \\
\hline Albizia amara & 3 & 8.70 & 0.01 & 1.62 & 0.01 \\
\hline Acacia drepanolobium & 2 & 5.10 & 0.01 & 1.08 & 0.01 \\
\hline Grewia arborea & 15 & 3.75 & 0.00 & 8.11 & 0.01 \\
\hline Commiphora africana & 2 & 10.00 & 0.01 & 1.08 & 0.01 \\
\hline Commiphora truncata & 4 & 6.00 & 0.00 & 2.16 & 0.01 \\
\hline Opilia campestris & 4 & 6.20 & 0.00 & 2.16 & 0.01 \\
\hline Cordia monica & 15 & 2.61 & 0.00 & 8.11 & 0.00 \\
\hline Acacia sp & 1 & 10.60 & 0.01 & 0.54 & 0.00 \\
\hline Maerua triphylla & 4 & 3.25 & 0.00 & 2.16 & 0.00 \\
\hline Ipomoea donaldsonii & 3 & 3.10 & 0.00 & 1.62 & 0.00 \\
\hline Grewia sp & 4 & 2.50 & 0.00 & 2.16 & 0.00 \\
\hline Dulfelid & 6 & 2.50 & 0.00 & 2.16 & 0.00 \\
\hline
\end{tabular}




\subsubsection{Importance Value Index (IVI)}

The Importance Value Index (IVI) is important to compare the ecological significance of species [3, 4]. The most important tree/shrub species in Higelely dry forest were: Acacia oerfota, Acacia mellifera, Acacia bussie, Boscia minimifolia, Balanites glabra, and Acacia senegal (with IVI values of $>10$ ). Species with low IVI values in this forest includes: Acacia sp, Ipomoea donaldsonii, Commiphora africana, Grewia sp and Acacia drepanolobium (with priority rank of $1-5)$. Seventy percent of the species had IVI value of $1-10$ (Table 5).

Table 5. The IVI of woody species in Higelely dry forest.

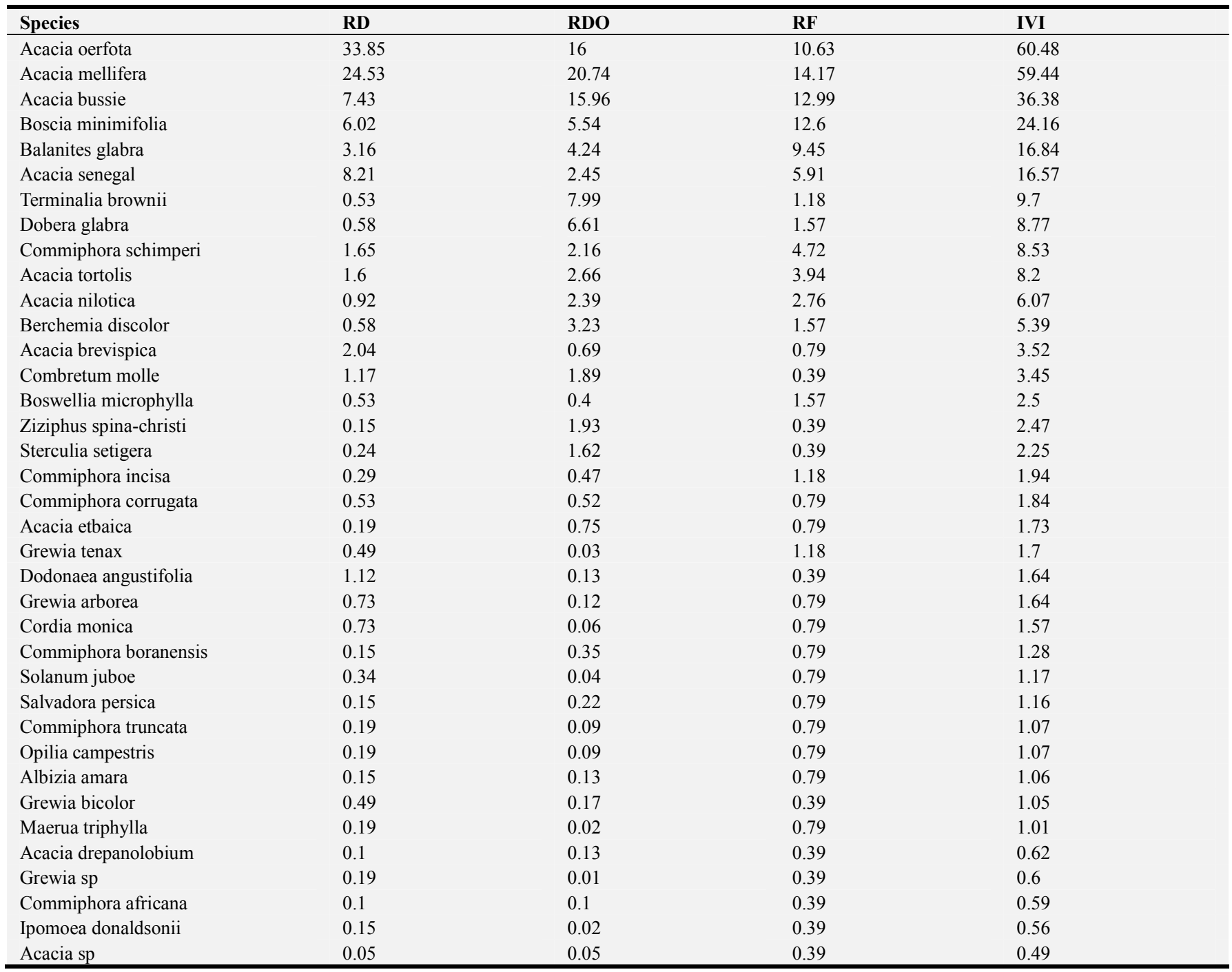

Note: $\mathrm{RD}=$ Relative Density, $\mathrm{RDO}=$ Relative Dominance, RF=Relative Frequency.

\subsubsection{Population Structures}

The population structure of woody species in Higelely dry forest were grouped under three distinct types of patterns such as species with bad reproduction (lower number of regeneration) and bad recruitment (Group 1); species with good reproduction but bad recruitment (Group 2); and species with good reproduction and good recruitment (Group 3).

Accordingly, about $55 \%$ of the species of Higelely dry forest were in Group1, 31.5\% in Group 2 and 13\% in Group 3 (Table 6). According to the species population structure analysis all species in Group 1 are the first priority, species in Group 2 are the second priority and those in Group 3 are the third priority for genetic conservation.

\subsection{Regeneration Status}

Three specimens identified to species level were recorded as seedlings in Higelely forest, belonging to 3 genera and 3 families. Only $31.6 \%$ of the species recorded as matured species were represented in the seedling count in this forest. The total density of seedlings in Higelely forest was 1047.3 individuals per ha. The four species with high value in seedling were: Acacia oerfota, Acacia bussie, Grewia tenax and Acacia mellifera (with density value $>100$ per ha). 
Table 6. Species list in the three species population structures category.

\begin{tabular}{lll}
\hline Group 1 & Group 2 & Group 3 \\
\hline Species name & Species name & Species name \\
\hline Acacia drepanolobium & Acacia brevispica & Acacia bussie \\
Acacia etbaica & Acacia nilotica & Acacia mellifera \\
Acacia sp & Acacia senegal & Acacia oerfota \\
Albizia amara & Acacia tortolis & Boscia minimifolia \\
Berchemia discolor & Boswellia microphylla & Balanites glabra \\
Combretum molle & Commiphora corrugata & \\
Commiphora africana & Commiphora incisa & \\
Commiphora boranensis & Commiphora schimperi & \\
Commiphora truncata & Dodonaea angustifolia & \\
Cordia monica & Grewia arborea & \\
Dobera glabra & Grewia bicolor & \\
Dulfelid & Solanum juboe & \\
Grewia sp & & \\
Grewia tenax & & \\
Ipomoea donaldsonii & & \\
Maerua triphylla & & \\
Opilia campestris & & \\
Salvadora persica & & \\
Sterculia setigera & & \\
Terminalia brownii & & \\
Ziziphus spina-christi & & \\
\hline
\end{tabular}

One specimen identified to species level was recorded as saplings in Higelely forest. $57.9 \%$ of the species recorded as matured species were represented in the sapling count in this forest. The total sapling density of this forest was 3033.77 individuals per ha. Species with high sapling density in this forest were: Acacia oerfota, Acacia mellifera, Acacia senegal, Boscia minimifolia, Grewia tenax, Acacia bussie, Acacia tortolis and Acacia brevispica (with sapling density of 851-101). 81\% of the sapling density in Higelely forest was contributed by these species (Table 7).

The assessment of regeneration will help in decision on feasibility of conservation efforts for sustainable use. The results of the inventory show a gap between the floristic composition of the matured stand and the regeneration. There were some matured dry forest species, which lack seedlings and /or saplings. This might suggest that their regeneration from seedlings and/or saplings would be unlikely once matured individuals disappeared and these species are under threat of local extinction.

In analyzing the conservation status and for the sake of priority setting of all the species encountered in this forest, the species were classified into three groups based on total regeneration density. Those species, which are totally absent in the regeneration, are grouped under Group 1; others whose density is greater than zero but less than 50 are under Group 2 and those with density of greater than or equal to 50 are Group 3. Accordingly, the species in-Group 1 is first priority, Group 2 second priority and Group 3 third priorities for conservation. From all tree/shrub species encountered in this forest, about $35.7 \%$ were found in Group 1, 28.5\% in Group 2 and $35.7 \%$ in Group 3 (Table 8).

The relative abundance, distribution and growth of seedlings and/or saplings in the understory are important in determining species that replace the canopy. However, abundance of seedlings and/or saplings should by no means an indicator of the definitive establishment of young individuals. This is because for many indigenous tree/shrub species the seedlings and /or saplings are often not easy to establish since the microhabitat in which regeneration occurs might not be a suitable environment for establishment. Therefore, further study and monitoring of the natural regeneration in designated conservation areas is required.

\subsection{Conservation Priority of Woody Species}

For the actual determination of the conservation status of all the species of this forest, the importance value index (IVI), population structure and regeneration status of all the species encountered in the area were analyzed. The woody species with lower values in IVI are taken as rare species and in need of conservation measure. On the other hand, even though some species had higher value in IVI, their species population structure showed that bad reproduction and bad recruitment. The woody species which have bad reproduction and bad recruitment are the first priority species to be considered for conservation. In the case of analyzing the conservation status by regeneration status, those species without regeneration are the first priority species to be considered for conservation.

In setting the priority rank, the IVI selection criteria, population structure criteria and regeneration status criteria were considered to have equal values. If a species is found in the mentioned criteria, the species will get 1 , if not 0 . Then these values will be added and the species will be prioritized by the total values of the three scores that the species will get. From the selected 24 priority species $16.7 \%$ were selected by the three criteria, $37.5 \%$ by two of the criteria and $45.8 \%$ were selected by one of the three criteria (Table 9). 
Dry Forest, Eastern Ethiopia: Implication for Conservation Priority

Table 7. The seedling and sapling records of Higelely dry forest.

\begin{tabular}{|c|c|c|c|}
\hline Species & Seedling/ha & Sapling/ha & Total \\
\hline Acacia brevispica & 20.27 & 101.35 & 121.62 \\
\hline Acacia bussie & 175.68 & 128.38 & 304.06 \\
\hline Acacia drepanolobium & 0 & 0 & 0 \\
\hline Acacia etbaica & 27.03 & 27.03 & 54.06 \\
\hline Acacia mellifera & 114.86 & 608.11 & 722.97 \\
\hline Acacia nilotica & 0 & 0 & 0 \\
\hline Acacia oerfota & 195.95 & 851.35 & 1047.3 \\
\hline Acacia senegal & 47.3 & 243.24 & 290.54 \\
\hline Acacia sp & 0 & 0 & 0 \\
\hline Acacia tortolis & 67.57 & 108.11 & 175.68 \\
\hline Albizia amara & 0 & 0 & 0 \\
\hline Balanites glabra & 0 & 40.54 & 40.54 \\
\hline Berchemia discolor & 0 & 13.51 & 13.51 \\
\hline Boscia minimifolia & 67.57 & 236.49 & 304.06 \\
\hline Boswellia microphylla & 0 & 74.32 & 74.32 \\
\hline Combretum molle & 0 & 0 & 0 \\
\hline Commiphora africana & 0 & 0 & 0 \\
\hline Commiphora boranensis & 0 & 13.51 & 13.51 \\
\hline Commiphora corrugata & 0 & 0 & 0 \\
\hline Commiphora incisa & 0 & 74.32 & 74.32 \\
\hline Commiphora schimperi & 0 & 40.54 & 40.54 \\
\hline Commiphora truncata & 0 & 6.76 & 6.76 \\
\hline Cordia monica & 0 & 6.76 & 6.76 \\
\hline Dobera glabra & 0 & 0 & 0 \\
\hline Dodonaea angustifolia & 0 & 0 & 0 \\
\hline Dulfelid & 0 & 0 & 0 \\
\hline Grewia arborea & 27.03 & 54.05 & 81.08 \\
\hline Grewia bicolor & 0 & 6.76 & 6.76 \\
\hline Grewia sp & 0 & 54.05 & 54.05 \\
\hline Grewia tenax & 135.14 & 182.43 & 317.57 \\
\hline Ipomoea donaldsonii & 0 & 0 & 0 \\
\hline Maerua triphylla & 0 & 0 & 0 \\
\hline Opilia campestris & 0 & 0 & 0 \\
\hline Salvadora persica & 0 & 0 & 0 \\
\hline Solanum juboe & 54.05 & 67.57 & 121.62 \\
\hline Sterculia setigera & 6.76 & 0 & 6.76 \\
\hline Terminalia brownii & 0 & 13.51 & 13.51 \\
\hline Ziziphus spina-christi & 0 & 0 & 0 \\
\hline Grewia flavescens & 74.32 & 67.57 & 141.89 \\
\hline Sida rhombifolia & 27.03 & 0 & 27.03 \\
\hline Solanum incanum & 6.76 & 0 & 6.76 \\
\hline Ipomoea spathulata & 0 & 13.51 & 13.51 \\
\hline Total & 1047.32 & 3033.77 & 4081.09 \\
\hline
\end{tabular}

Table 8. List of species under regeneration status group.

\begin{tabular}{llllll}
\hline No & Group 1 & No & Group 2 & No & Group 3 \\
\hline 1 & Acacia drepanolobium & 1 & Balanites glabra & 1 & Acacia oerfota \\
2 & Acacia nilotica & 2 & Commiphora schimperi & 2 & Acacia mellifera \\
3 & Acacia sp & 3 & Sida rhombifolia & 3 & Grewia tenax \\
4 & Albizia amara & 4 & Berchemia discolor & 4 & Acacia bussie \\
5 & Combretum molle & 5 & Commiphora boranensis & 5 & Boscia minimifolia \\
6 & Commiphora africana & 6 & Terminalia brownii & 6 & Acacia senegal \\
7 & Commiphora corrugata & 7 & Ipomoea spathulata & 7 & Acacia tortolis \\
8 & Dobera glabra & 8 & Commiphora truncata & 8 & Grewia flavescens \\
9 & Dodonaea angustifolia & 9 & Cordia monica & 9 & Acacia brevispica \\
10 & Dulfelid & 10 & Grewia bicolor & 10 & Solanum juboe \\
11 & Ipomoea donaldsonii & 11 & Sterculia setigera & 11 & Grewia arborea \\
12 & Maerua triphylla & 12 & Solanum incanum & 12 & Boswellia microphylla \\
13 & Opilia campestris & & & 13 & Commiphora incisa \\
14 & Salvadora persica & & & 14 & Acacia etbaica \\
15 & Ziziphus spina-christi & & & 15 & Grewia sp \\
\hline
\end{tabular}


Table 9. List of all the species selected by IVI, population structure and regeneration status criteria.

\begin{tabular}{|c|c|c|c|c|c|}
\hline \multirow{2}{*}{ Species name } & \multicolumn{3}{|c|}{ Threat status selection criteria } & \multirow{2}{*}{ Total score } & \multirow{2}{*}{ Priority rank } \\
\hline & IVI & Population structure & Regeneration status & & \\
\hline Acacia drepanolobium & 1 & 1 & 1 & 3 & 1 \\
\hline Commiphora africana & 1 & 1 & 1 & 3 & 1 \\
\hline Ipomoea donaldsonii & 1 & 1 & 1 & 3 & 1 \\
\hline Acacia sp & 1 & 1 & 1 & 3 & 1 \\
\hline Grewia sp & 1 & 1 & & 2 & 2 \\
\hline Albizia amara & & 1 & 1 & 2 & 2 \\
\hline Combretum molle & & 1 & 1 & 2 & 2 \\
\hline Dobera glabra & & 1 & 1 & 2 & 2 \\
\hline Dulfelid & & 1 & 1 & 2 & 2 \\
\hline Maerua triphylla & & 1 & 1 & 2 & 2 \\
\hline Opilia campestris & & 1 & 1 & 2 & 2 \\
\hline Salvadora persica & & 1 & 1 & 2 & 2 \\
\hline Ziziphus spina-christi & & 1 & 1 & 2 & 2 \\
\hline Acacia etbaica & & 1 & & 1 & 3 \\
\hline Berchemia discolor & & 1 & & 1 & 3 \\
\hline Commiphora boranensis & & 1 & & 1 & 3 \\
\hline Commiphora truncata & & 1 & & 1 & 3 \\
\hline Cordia monica & & 1 & & 1 & 3 \\
\hline Grewia tenax & & 1 & & 1 & 3 \\
\hline Sterculia setigera & & 1 & & 1 & 3 \\
\hline Terminalia brownii & & 1 & & 1 & 3 \\
\hline Acacia nilotica & & & 1 & 1 & 3 \\
\hline Commiphora corrugata & & & 1 & 1 & 3 \\
\hline Dodonaea angustifolia & & & 1 & 1 & 3 \\
\hline
\end{tabular}

For the actual implementation of the genetic conservation measures of these species, the ecological demands and reproduction systems of each species has to be known. Even though there is limited information on the ecological requirements and reproduction systems of the species, conservation measures should be applied [22]. Therefore, for the conservation of priority woody species in Higelely dry forest, in-situ conservation strategy is recommended to allow the natural regeneration and recruitment. In addition to this, the seed storage and germination behavior of the species are required to conserve the species in ex-situ conservation strategy such as cold room storage and plantation in their suitable habitats.

\section{Conclusions and Recommendations}

Higelely forest should be seen as one of the biodiversity conservation area because of the fact that it is one of highly threatened dry forest areas in the region. This forest had about 42 woody species, which belong to 15 families. This forest was heavily exploited forest in the past and still continuous to be heavily impacted by human interference. There is a continued cutting of trees and forest clearance by local people and this disturbance has affected the species composition and structure of the forest. Based on current trends of disturbance in Higelely dry forest, inevitably genetic erosion will be caused. Therefore, taking the appropriate genetic conservation measure is the timely action.

To conserve the forest genetic resources, to improve the natural diversity and structure of the forest and to gain optimal ecological and economical benefit of the forest, insitu conservation site establishment is recommended. Further study on the population and population distribution of the priority selected species is essential for effective conservation measures. Increase public awareness on the forest genetic resource values and the problems related to loss of genetic information is also needed. Create alternatives and mechanisms by which human impacts can be minimized through discussion and consultation with the local community should be the other current action. In addition, seed collection and storage in cold room should be applied for species which could produce orthodox seed.

\section{Data Availability}

The data can be made available from the corresponding author upon request.

\section{Conflicts of Interest}

All the authors do not have any possible conflicts of interest.

\section{Acknowledgements}

We are gratefully acknowledging the support of Ethiopian Biodiversity Institute, Somali national regional state, Jerer zone and Deghabur district natural resource offices and experts. We are also indebted Tewodros Misganaw who 
supported us during data collection.

\section{References}

[1] Dessie, G. and Kleman, J., 2007. Pattern and magnitude of deforestation in the South Central Rift Valley Region of Ethiopia. Mountain research and development, 27 (2), pp. 162-168.

[2] Othow, O. O., Gebre, S. L. and Gemeda, D. O., 2017. Analyzing the rate of land use and land cover change and determining the causes of forest cover change in Gog district, Gambella regional state, Ethiopia. J. Remote Sens. GIS, 6 (4), p. 218.

[3] Awoke, H. and Mewded, B., 2019. Changes in woody species composition and structure of Denkoro dry evergreen Afromontane forest over 16 years (2001-2017), South Wollo, Ethiopia. Forest Ecology and Management, 441, pp. 71-79.

[4] Mewded, B., Negash, M. and Awas, T., 2019. Woody species composition, structure and environmental determinants in a moist evergreen Afromontane forest, southern Ethiopia. Journal of Forestry Research, pp. 1-14.

[5] Shiferaw, D. and Suryabhagavan, K. V., 2019. Forest degradation monitoring and assessment of biomass in Harenna Buluk District, Bale Zone, Ethiopia: a geospatial perspective. Tropical ecology, 60 (1), pp. 94-104.

[6] Mohammed, K. A., Kawo, K. N. and Robe, E., 2020. Evaluation of Fuel Wood Consumption and Its Implication to Forest Degradation in Agarfa Wereda, South-Eastern Ethiopia. Evaluation, 62 .

[7] Temesgen, G., Amare, B. and Silassie, H. G., 2014. Land degradation in Ethiopia: causes, impacts and rehabilitation techniques. Journal of environment and earth science, 4 (9), pp. 98-104.

[8] Ayele, A. W. and Zewdie, M. A., 2017. Modeling and forecasting Ethiopian human population size and its pattern. International Journal of Social Sciences, Arts and Humanities, 4 (3), pp. 71-82.

[9] EFAP. 1994. Ethiopian Forest Action Program. Volume I, II, III and IV. Final Report, MoNRDEP, EFAP Secretariat, Addis Ababa.

[10] Beyene, A., Bluffstone, R., Gebreegzhiaber, Z., Martinsson, P., Mekonnen, A. and Vieider, F., 2015. Do improved biomass cookstoves reduce fuelwood consumption and carbon emissions? Evidence from rural Ethiopia using a randomized treatment trial with electronic monitoring. The World Bank.
[11] Mori, A. S., Lertzman, K. P. and Gustafsson, L., 2017. Biodiversity and ecosystem services in forest ecosystems: a research agenda for applied forest ecology. Journal of Applied Ecology, 54 (1), pp. 12-27.

[12] Ren, Y., Lü, Y., Fu, B. and Zhang, K., 2017. Biodiversity and ecosystem functional enhancement by forest restoration: A meta-analysis in China. Land Degradation \& Development, 28 (7), pp. 2062-2073.

[13] Carugati, L., Gatto, B., Rastelli, E., Martire, M. L., Coral, C., Greco, S. and Danovaro, R., 2018. Impact of mangrove forests degradation on biodiversity and ecosystem functioning. Scientific reports, 8 (1), pp. 1-11.

[14] Plas, F., 2019. Biodiversity and ecosystem functioning in naturally assembled communities. Biological Reviews, 94 (4), pp. 1220-1245.

[15] Kangas, A. and Maltamo, M. eds., 2006. Forest inventory: methodology and applications (Vol. 10). Springer Science \& Business Media.

[16] Wale, H. A., Bekele, T. and Dalle, G., 2012. Floristic diversity, regeneration status, and vegetation structure of woodlands in Metema Area, Amhara National Regional State, and Northwestern Ethiopia. Journal of Forestry Research, 23 (3), pp. 391-398.

[17] Work, A., Teketay, D., Lemenih, M. and Fetene, M., 2012. Diversity, regeneration status, and population structures of gum and resin producing woody species in Borana, Southern Ethiopia. Forests, Trees and Livelihoods, 21 (2), pp. 85-96.

[18] Melaku, K., 2008. Forest genetic resource conservation data base. GTZ, Addis Ababa

[19] Lamprecht, H., 1989. Silviculture in the tropics: tropical forest ecosystems and their tree species: possibilities and methods for their long-term utilization (No. 634.95 L239s ing.). Eschborn, DE: GTZ.

[20] Fangliang, H., Legendre, P. and LaFrankie, J. V., 1997. Distribution patterns of tree species in a Malaysian tropical rain forest. Journal of vegetation Science, 8 (1), pp. 105-114.

[21] Schulz, B., 2009. Sampling and estimation procedures for the vegetation diversity and structure indicator (Vol. 781). US Department of Agriculture, Forest Service, Pacific Northwest Research Station.

[22] Schroth, G., Ferreira Da Silva, L., Wolf, M. A., Geraldes Teixeira, W. and Zech, W., 1999. Distribution of throughfall and stemflow in multi-strata agroforestry, perennial monoculture, fallow and primary forest in central Amazonia, Brazil. Hydrological Processes, 13 (10), pp. 1423-1436. 